\title{
With Gratitude on Veterans Day
}

Leslie V. Simon, DO

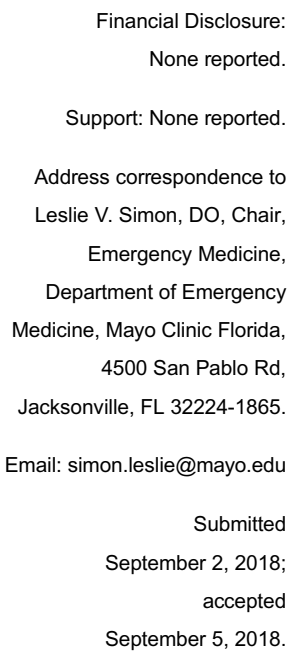

September 5, 2018.

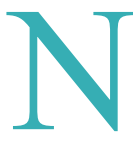

ovember 11 was originally Armistice Day, a celebration of peace on the first anniversary marking the end of World War I. It has evolved into Veterans Day, a day to honor those who have served in the military, who continue to serve in uniform, and who have died in service to our country. Less than $10 \%$ of the population can call themselves a veteran, ${ }^{1}$ and when you consider the impact these individuals have had on the world, you realize what gratitude is owed by so many to so few.

I grew up in a military family. My grandfather served in the Army Corps of Engineers during World War II, and my father is a career Naval aviator and Vietnam veteran. I wish I could say that I joined the Navy out of a sense of tradition, duty, and patriotism, but that's not how it was. The truth is, I wanted to become a physician and did not have the money to put myself through medical school. When the Navy offered me a commission and full scholarship under the Navy Health Professions Scholarship Program, I jumped at the chance. After all, it was peacetime, and my job would be to practice medicine and to take care of patients, which didn't seem much different from what I would be doing in the civilian world as a physician.

On September 11, 2001, I was an Emergency Medicine resident at the Naval Medical Center in San Diego, California. I was standing in a patient's room when I heard what had happened in New York and at the Pentagon. As I watched the planes fly into the World Trade Center again and again on the television, I was devastated by the assault on my country. I also realized that what it meant to serve in the military was about to change.

When most people think about the Navy, they think about aircraft carriers covered in fighter jets or hospital ships like the Comfort and the Mercy that serve humanitarian aid missions all over the world. What many people do not realize is that
Navy Medicine also provides health care for the Marines. In my decade of service as a naval officer, I never spent the night on a ship because I was assigned to the Marine Corps.

The Marines are sometimes affectionately referred to as the "pointy end of the spear." Along with the Navy SEALS and the other special forces, they take on some of the most dangerous missions of the military. As Ronald Reagan is often quoted, "Some people go their whole lives wondering if they have made a difference in the world. The Marines don't have that problem."

In Operation Iraqi Freedom and Operation Enduring Freedom (Afghanistan), the United States has had the most severely injured casualties since Vietnam. But of the injured, more than $90 \%$ will survive - many of whom would never have survived another conflict. There are several reasons for this: better gear, faster evacuation, and some incredible advances in battlefield medicine, which have revolutionized both military and civilian trauma practice. The Marines attribute their high survival rates to putting their resources closer to the point of injury. I thought this sounded like a great plan until I realized that as an emergency physician, I was considered a resource.

I left for deployment on my twin girls' first birthday. At the time, I had 4 children under the age of 5 that I was leaving for 8 months. To be perfectly honest, nobody wanted me to go less than I did. But once I was there, everything changed. As the patients poured in with some of the most devastating injuries I had ever seen, I realized what patriotism, honor, and courage really mean. I learned it from my colleagues - the doctors, nurses, and corpsmen working alongside me. More importantly, I learned it from my patients, several of whom were still children on September 11, 2001. I may have missed my oldest son's first day of kindergarten and my twin girls' first words and first steps, but what I had given up paled in 
comparison to the sacrifices made by my patients. Many of them gave their lives, their limbs, their eyesight, and their emotional well-being. And they gave this voluntarily, in service to their country. I also realized that what I was doing really mattered. I realized I was very well trained and capable of providing the care these patients deserved and that most of them would survive to go home to their families because their "resources were close to the point of injury." It was an incredible privilege to be their physician, and it was the most professionally rewarding thing I will ever do.

Had this been World War I, I would not have been able to serve in the military because I am a woman. ${ }^{2}$ Had this been World War II, I would not have been permitted to serve because I am an osteopathic physician. ${ }^{3}$ I'm grateful to my country and my profession for the progress that has been made. I will always be grateful to the Navy for my education, my exceptional training, the camaraderie of my colleagues, and the opportunity to know that I made a difference in the world. As physicians, we are provided with multiple opportunities to rise to an occasion; the Navy taught me to never pass one up.
For those of you who have served in the military, in peacetime or in war, thank you for your service to our country. I'm proud to be one of you. And for those of you who have not served in the military, thank you for reading this. Even if you have never put on a uniform, your support of those who have is every bit as important. When I deployed, my sister quit her job and she and her husband moved in with my husband to help raise my children. It's not the kind of thing you could ever ask of someone or ever repay. In my book, my sister is a bigger hero than I will ever be. Happy Veterans' Day, with much gratitude. (doi:10.7556/jaoa.2018.154)

\section{References}

1. Bialik K. The changing face of America's veteran population. Pew Research Center. http://www.pewresearch.org/fact-tank/2017/11/10/ the-changing-face-of-americas-veteran-population/. Published November 10, 2017. Accessed September 21, 2018.

2. American women physicians in World War I. American Medical Women's Association website. https://www.amwa-doc.org/ wwi-exhibition/. Accessed July 18, 2017.

3. Silver SA. Thanks, but no thanks: how the denial of osteopathic service in World War I and World War II shaped the profession. J Am Osteopath Assoc. 2012;112(2):93-97.

๑ 2018 American Osteopathic Association 